\title{
ABORTION: The International Agenda
}

At the time of going to press, David Alton's bill, restricting the time limit for abortion to the end of the 17th week after conception, has just passed its second reading in the British House of Commons. By the time this issue of Feminist Review reaches the bookshops, it will have become law or been defeated. For the fifth time since its passing, the women's movement in Britain is having to mobilize in defence of the 1967 Abortion Act (which allows abortion for specified health reasons, on the authority of two doctors).

If Alton's bill succeeds, it will have serious repercussions not only in Britain, but beyond. The articles on Ireland and Spain illustrate the difficulties already faced by women who have to travel to England to the private clinics here, because of the unavailability of abortion in their own countries.

The articles on Nicaragua and Hungary show that even in socialist countries with relatively progressive policies on women's rights there is strong opposition to women's control over reproduction, which only a strong and independent feminist movement could overcome. However, as the articles by Marge Berer and Karen Coleman show, although 'a woman's right to choose' is nowhere constitutionally enshrined, the struggle to achieve abortion rights has included many from outside the feminist movement.

By contrast, the article on China, and Susan Himmelweit's exploration of issues surrounding the slogan 'A Woman's Right to Choose', raise issues for women beyond the necessity of freely available abortion. 